ZESZYTY NAUKOWE UNIWERSYTETU SZCZECIŃSKIEGO

NR 884

EKONOMICZNE PROBLEMY USŁUG NR 119

2015

DOI: 10.18276/epu.2015.119-04

\author{
Ilona Urbanyi-Popiołek*
}

\title{
THE ECONOMIC ASPECTS \\ OF THE FERRY OPERATOR ACTIVITY - SELECTED ISSUES
}

\begin{abstract}
The ferry industry is well-developed within the Baltic Sea. The ferry operation is a type of liner shipping where passengers and cargo form one specific market. The costs incured by ferry companies are typical for regular shipping, whereas revenue is generated in two different segments. The aim of the article is to analyse the structure of costs and income of ferry carriers. Two prime Baltic companies operating cruise ferries have been analysed.
\end{abstract}

Keywords: ferry operator, costs, revenue

\section{Introduction}

Ferry shipping is a type of liner trade where passengers and cargo form one market. Ferries can be defined as ships with passenger accommodation and space for wheeled cargo. Ro-ro technology is used for loading/discharging vehicles. Ferries sail on regular routes. (Market 2012: 12,16). Some ferry companies operate pure ro-ros as well. Stopford states that ships operate ferry markets share many common characteristic such as car decks, accommodation for passengers

* Ilona Urbanyi-Popiołek, PhD, Gdynia Maritime University, Faculty of Entrepreneurship and Quality Science, e-mail address: i.urbanyi@wpit.am.gdynia.pl. 
and entertainment facilities but there are so many combinations of these basic characteristics that make the ferry fleet a diverse phenomenon (Stopford 2009: 501). The main types of vessels used in the ferry industry to be considered in this article are cruise ferries and ro-paxes.

The purpose of this paper is to present the structure of costs and revenue of ferry companies operating within the Baltic Sea and to analyse the two items influencing the financial performance of the company. The research question focuses on the comparison of two main types of ships involved in the industry within the Baltic area - cruise ferries and ro-paxes.

The paper is organized as follows: Section 1 elaborates the ferry market at the Baltic Sea. In Section 2 an analysis of running costs of ships has been given. Section 3 presents the revenue of ferry companies. Conclusions are addressed in last section.

The methodology used in this study is based on the analysis of statistics and companies' financial reports as well as deductive reasoning.

\section{Baltic Sea ferry market}

The Baltic Sea is one of the prime ferry markets. In 2014 the total Baltic traffic amounted to 240 million passengers, 93,7 million cars and 11,8 million trailers. These figures include all main and local routes between islands in the whole region. As regards the international and main domestic services (a few Danish and Swedish domestic routes), the ferries carried nearly 49 million passengers, 9,5 million cars and 3,5 million cargo units (Market 2015: 25, 180-198). The pure ro-ro cargo traffic is not included.

In relation to the international market, the ferry shipping within the Baltic is consolidated. 17 ferry companies work in this area operating about 120 ferries of different types (cruise-trailer, ro-pax, cargo, high speed). For cargo, the most convenient vessels are ro-paxes and ro-ro ferries with space for drivers. They operate in services where lorries and trailers dominate. Cruise-trailer ships have also large capacity for the wheeled cargo, but they are put on markets with huge passenger demand, for example Finland - Estonia, Sweden - Finland, Norway - Germany.

The biggest concentration of the ferry industry occurs in the western Baltic and Danish Straits. This market services $60 \%$ of the total number of passen- 
gers and $70 \%$ of the cargo carried within the Baltic. Cargo dominates in Sweden - German and Sweden - Denmark markets. This region has utilized 49 vessels operated primarily by Stena Line, TT-Line, DFDS Seaways and Color Line.

The second region is the eastern Baltic, with the services from Finland to Sweden and Estonia. This market has the $32 \%$ share in passenger traffic and $15 \%$ in cargo turnover. The number of ferries employed in this area amounts to 31 . The main operators are Tallink Group (Silja Line and Tallink) and Viking Line. The major services are Stockholm - Helsinki, Stockholm - Turku and Helsinki - Tallinn. The passenger traffic and package tours are very popular in this region, so cruise-trailer ferries prevail.

The southern Baltic contains services from Sweden to Poland, Lithuania and Latvia. The market has the $8 \%$ share in passenger and $15 \%$ in cargo. The traffic between Poland and Sweden dominates in this area and is growing every year. The leading companies in this region are Unity Line, Stena Line and TT-Line.

Table 1. Main ferry operators within the Baltic Sea

\begin{tabular}{|c|c|c|c|c|c|c|}
\hline Carrier & \multicolumn{2}{|c|}{ Number of ships } & \multicolumn{2}{c|}{ Ferries } & \multicolumn{2}{c|}{ Pure ro-ros } \\
\hline & 2013 & 2014 & 2013 & 2014 & 2013 & 2014 \\
\hline Stena Line & 18 & 22 & 15 & 19 & 3 & 3 \\
\hline Finnlines & 24 & 23 & 14 & 11 & 10 & 13 \\
\hline Tallink/Silja Line & 15 & 13 & 12 & 11 & 3 & 2 \\
\hline Viking Line & 7 & 7 & 7 & 7 & & \\
\hline DFDS Seaways & 14 & 15 & 4 & 6 & 10 & 9 \\
\hline Unity Line & 7 & 7 & 7 & 7 & & \\
\hline Color Line & 6 & 6 & 6 & 6 & & \\
\hline TT-Line & 6 & 6 & 6 & 6 & & \\
\hline
\end{tabular}

Source: the author's own elaboration based on Shippax Market (2013), ShipPax Market Statistics, Plus 2 Ferryconsultation AB, Halmstad, Shippax Market (2014), ShipPax Market Statistics, Plus 2 Ferryconsultation AB, Halmstad.

Ferry services are generally operated by large companies. These companies compete in servicing the same routes or lines to the same destinations (Stopford 2009: 501). Thus, the price policy and quality of services are the basic issues, and so are the level of cost and incomes influencing the financial performance. 


\section{Costs of the ferry company}

Ferry operators incur costs generated in several areas of activity. Generally, the costs of running a ferry company are a combination of the three areas: cost related to fleet operation, costs of the company maintenance, and costs of marketing and land services designed for passengers and cargo owners. The ferry operation-generated expenses are fundamental as they determine the financial performance of the business.

The methodology of cost classification in the shipping industry is not unified, a fact which makes it difficult to analyse and compare different categories of costs. In general, costs can be classify into six categories (Stopford 2009: 221):

- operating costs constituting the ship-running expenses such as crew, stores and maintenance incurred with the ship trading,

- voyage costs including fuel expenses, port charges, canal dues: these are the specific voyage-related costs,

- periodic cost of maintenance incurring with ship' seaworthily, such as the costs of surveys, dry docking, repairs, insurance,

- cargo handling costs including loading and discharging operations and stevedoring expenses,

- capital costs resulting from the way of financing the ship and including depreciation, interest and capital payment etc.,

- other costs, administrative costs.

The structure and orchestration of costs depend on several factors such as e.g. ship type and size, age, flag, and way of operation.

The costs in ferry shipping are unique as they comprise expenses typical for freight shipping and passenger transportation by sea. The structure of ferry ship costs is as follows (Kizielewicz, Urbanyi-Popiołek 2015: 182-183):

- operating costs - crew costs, cost of goods sold, other operating costs (expenses for water, sanitary stores, collection of waste),

- voyage costs - bunker, port fees,

- handling costs - loading and discharging of wheeled cargo, private cars, buses, embarkation and disembarkation of passengers, services at ferry terminals,

- costs of maintenance - repairs, dry docking, surveys, insurance,

- capital costs - depreciation, charter hire, interest, capital payments on debt finance. 
The operating costs constitute $50-65 \%$ of the total cruise ferry costs. The largest are the expenses for the purchase of goods to shops and restaurants. These expenses approximate $30 \%$ of the total cruise ferry costs. The above items account for $50 \%$ of costs on ship-plying routes in the eastern Baltic and connections with Norway, where duty free sales are provided. They also comprise the expenses for the passenger servicing such as entertainment, spa\&wellness, gambling. Ergo, the above costs are the expenses associated with direct passenger services on-board.

The crew costs include all the charges incurred in relation to crewing the ferry such as e.g. salaries and wages, social insurance, pensions and victuals. Crew costs of cruise ferries constitute $20-25 \%$ of all operating costs. The number of hotel staff members increases the crew expenses. This item is lower on ro-pax as the number of crew is lesser. The other factor is the wages level. Some of the Baltic ferries are registered in national registers of shipping, for example Viking Line ships serve under the Swedish and the Finnish flag, Tallink Group ferries are registered under the Estonian and the Finnish flag, whereas Color Line - under the Norwegian one. The terms of employment under the national ensign increases the crew costs.

Other operation costs comprise such the expenses for hotel purchase stores, engine and deck departments, water supply and waste disposal. This group constitutes $10-15 \%$ of the total operating costs.

The voyage costs, the second group, includes the expenses for purchase of fuels and port fees. Fuel costs depend primarily on the fuel consumption and marine fuels prices. The fuel expenses are estimated for $12-20 \%$ of the running costs. Some carriers have implemented slow steaming (reduced vessel speeds) in recent years so as to improve fuel efficiency. On the other hand, the Baltic Sea has become a SECA area, hence operators are forced to use low sulphur fuels (or implement the alternative solutions such as scrubbers, LNG, methanol).

The port dues include various fees levied against the ferries such as tonnage dues, wharfage, quay dues, light dues, dockage and passenger dues. These expenses are charged according to port tariffs. Ferries calling ports regularly are charged lower fees depending on a number of calls over a definite period of time. Other items in this cost group are pilotage, towage and mooring. Ferry ships are exempt from these obligatory services when they are fitted with thrusters and captains have the pilot's licence. The handling costs are composed of two items. First, there are the expenses for loading and discharging of lorries, trailers and 
other wheeled cargo as well as cargo claims. Then, there are the expenses incurred in embarking and disembarking passengers and those comprising all terminal operations. It is estimated that the total of port expenses amounts to $7-15 \%$ as regards the cruise ferry operating.

Yet another cost group refers to the ship maintenance and comprises e.g. protection and indemnity insurance (P\&I), hull and machinery insurance (H\&M) as well as the periodic and routine maintenance expenses. The latter covers the costs of dry docking and special surveys to determine the ship 's seaworthiness. Further, this cost group includes maintaining the main engine and auxiliary equipment etc. It is estimated that the above mentioned expenses amount to $15 \%$ of the cruise ferry running costs.

The last cost group is the capital expenses such as depreciation (depending on the ferry value and method of writing off), payment of interest and repayment of loan. They account for $5-10 \%$ of the overall cost.

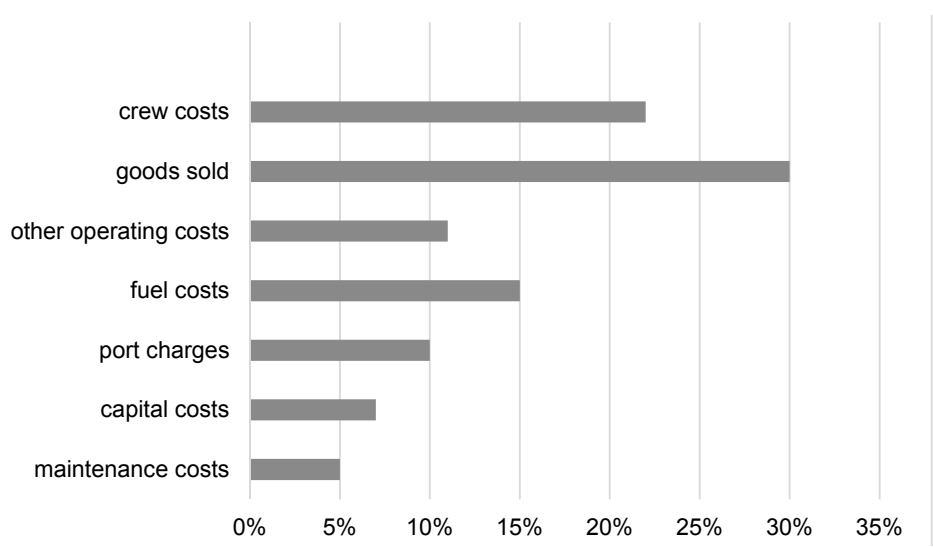

Figure 1. Running costs of the cruise ferry

Source: the author's own elaboration.

Figure 1 presents the typical structure of cruise ferry costs. The high share of the good sold is typical for the Baltic cruise ferries. On the lines where duty and tax-free sales on-board exist such as e.g. Sweden - Finland and Sweden - Estonia via Aland Islands and services outside the European Union, mini cruises and different packages are common. Differently from above at ro-pax expenses of goods purchase amount to $12-20 \%$ of total costs. 
Table 2. Running costs of Tallink-Silja Line and Viking Line in 2013

\begin{tabular}{|c|c|c|c|c|c|}
\hline & & \multicolumn{2}{|c|}{$\begin{array}{l}\text { Tallink - Silja Line } \\
\text { (13 ferries) }\end{array}$} & \multicolumn{2}{|c|}{$\begin{array}{l}\text { Viking Line } \\
\text { (7 ferries) }\end{array}$} \\
\hline & & $\begin{array}{l}\text { Value } \\
\text { in EUR } \\
(\mathrm{mln})\end{array}$ & $\begin{array}{c}\text { Share } \\
\%\end{array}$ & $\begin{array}{l}\text { Value } \\
\text { in EUR } \\
(\mathrm{mln})\end{array}$ & $\begin{array}{l}\text { Share } \\
\%\end{array}$ \\
\hline \multirow[t]{3}{*}{ Operating costs } & Crew costs & 135.05 & 17.9 & 130.6 & 26.8 \\
\hline & Goods sold & 220.20 & 30.0 & 150.1 & 30.8 \\
\hline & $\begin{array}{l}\text { Other operating } \\
\text { costs }\end{array}$ & 84.09 & 11.0 & 53.8 & 11.0 \\
\hline \multirow[t]{2}{*}{ Voyage costs } & Fuels costs & 129.82 & 17.3 & 62.4 & 12.8 \\
\hline & $\begin{array}{l}\text { Port charges } \\
\text { and handling }\end{array}$ & 96.29 & 12.8 & 41.7 & 8.6 \\
\hline Capital costs & $\begin{array}{l}\text { Depreciation/ } \\
\text { Interest/ } \\
\text { Charter hire }\end{array}$ & 65.05 & 8.4 & 31.7 & 6.6 \\
\hline Maintenance & & 21.28 & 2.6 & 16.7 & 3.4 \\
\hline Total & & 751,83 & 100 & 486.96 & 100 \\
\hline
\end{tabular}

Source: authors' own elaboration based on AS Tallink Group Consolidated Annual Report 2013, Tallinn 2014, pp. 54-55; Annual Report 2013, Viking Line, pp. 41-51.

Table 2 presents the cost structure of two leading companies operating cruise ferries. The choice of Tallink - Silja Line and Viking Line has been done not without reason. Firstly, both carriers operate only cruise-trailer ferries and do not have ro-pax or cargo ferries in their fleet, so the data are not distorted by the results of different types of ferry vessels in consolidated financial statements. Secondly, both operators apply similar methodology of costs classification so there is a possibility of comparing value and share of cost items. Other operator e.g. Stena Line, DFDS, operate ro-paxes as well as pure ro-ros and all data are presented in total. Furthermore, the cost items are calculated in different way, e.g. DFDS in operating costs reveals fuel and port operations.

Analysing the data presented in Table 2, it is noticeable that the similar cost share of goods sold - nearly $1 / 3$ of costs - is related to the services on-board. The higher level of crew costs in Viking Line effects from the nationality of crew members - Swedes and Finns are employees on Viking ships, whereas Tallink Group workers are mainly Estonian.

Ro-paxes and car ferries with limited space for passengers present a different cost structure. The main expenses are fuel and crew costs approximating 
$25 \%$ and $20 \%$ respectively. The cost of goods sold, as mention above, constitutes $12-20 \%$ of the total cost.

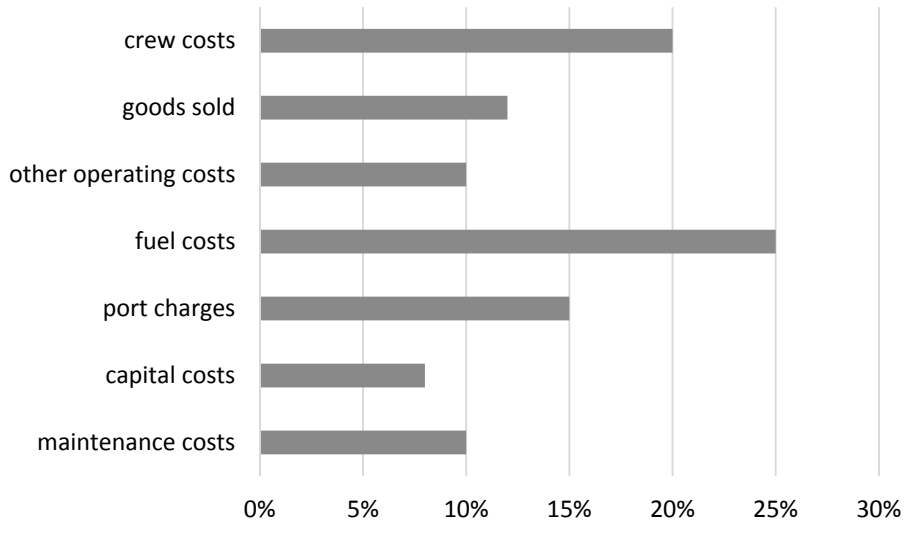

Figure 2. Running costs of ro-pax ferry

Source: the author's own elaboration.

\section{Revenue of the ferry company}

The service sales is the main source of ferry operator revenue. Differently from the other types of shipping, ferry operators get their incomes from two different areas - passenger and cargo. The revenue of the ferry company can be classified as follows:

- sales of tickets,

- sales of on-board services,

- other passengers revenue,

- sales of cargo transport,

- income from the charter of vessels.

The ticket sales is the first item of the passenger revenue and includes transport, sales of cabins and transport of private vehicles. The ferry operator uses the passenger tariffs showing the expenses of travelers covered by ticket. The accommodation expenses depend on the cabin category. The passenger tariff also includes the price of transportation of car, minibuses, caravans, motorbikes etc. The above category also comprises sales of package trips and conferences 
on-board. The prices of mini cruises represent integrated rates and include carriage, accommodation, sometimes also the stay in a hotel onshore.

Sales of on-board services include sales in restaurant and shops as well as entertainment. This item is the prime revenue that flows to the company-operating services with cruise philosophy developed. It is estimated that sales on-board generate $30-55 \%$ of the total revenue of cruise ferry. In the case of ro-pax, this category is of minor importance in relation to the cargo transportation and comprises $20-30 \%$ of the total earnings.

Other passengers' revenue contains the incomes which are not recognised as the on-board sale such as sales of packages by tour operators, passenger transfer, marketing, sales of hotel accommodation onshore etc.

The second important item is cargo segment revenue. This income is significant part of ro-paxes where cargo transportation dominates (up to $70 \%-80 \%$ of the total income). Lorries, trailers and other wheeled cargo are carried upon freight tariffs. The basic rates are charged per length of the vehicle or per unit. Typically for the liner service pricing, ferry companies charge freight additionals, like Bunker Adjustment Factor (BAF), Low Sulphur Surcharge (LSS), or the charge for vehicles containing dangerous goods. In practice operators frequently use service contracts with major customers offering discounts or other concessions.

The income from charters is a minor item concerning operators chartering out free tonnage instead of sale, e.g. Finnlines, Tallink - Silja Line charter ferries which have not been employed on companies route networks.

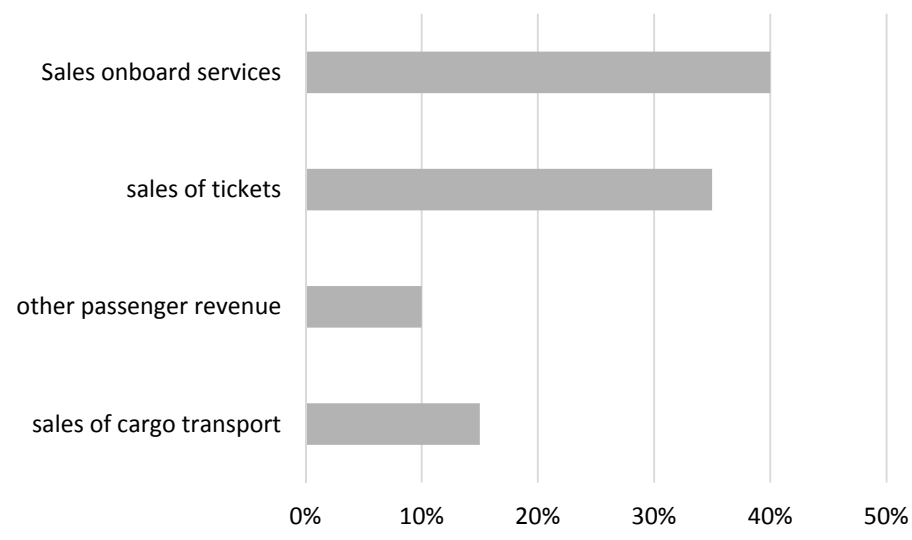

Figure 3. Revenue of the cruise ferry

Source: the author's own elaboration. 
The cruise ferry operation income differs in structure compared with ro-pax. On-board services generate on average as much as $40 \%$ of the total revenue. Catering and entertainment generate the expenditures of passengers being the primarily source of the cruise ferries income. Cargo segments amounts on average to $15-20 \%$ of this ferry type revenue.

Table 3. Revenue of selected ferry operators in 2013

\begin{tabular}{|c|c|c|c|c|c|c|}
\hline & \multicolumn{2}{|c|}{$\begin{array}{c}\text { Tallink Group } \\
\text { (in thousands } \\
\text { of EUR) }\end{array}$} & \multicolumn{2}{|c|}{$\begin{array}{c}\text { Viking Line } \\
\text { (in thousands } \\
\text { of EUR) }\end{array}$} & \multicolumn{2}{|c|}{$\begin{array}{c}\text { Fjord Line } \\
\text { (in thousands } \\
\text { of NOK) }\end{array}$} \\
\hline Sales on-board services & 507307 & 53,9 & 508800 & 93,3 & 111316 & 25,1 \\
\cline { 1 - 3 } \cline { 5 - 7 } Sales of tickets & 267184 & 28,3 & & & 191053 & 43,4 \\
\hline Other passengers revenue & 31167 & 3,3 & & & 62817 & 14 \\
\hline Sales of cargo transport & 105568 & 11,3 & 36500 & 6,7 & 77552 & 17.5 \\
\hline Income from charter of vessels & 30755 & 3,2 &. &. &. &. \\
\hline Total & 941983 & 100 & 545300 & 100 & 442738 & 100 \\
\hline
\end{tabular}

Source: the author's own elaboration based on AS Tallink Group Consolidated Annual Report 2013, Tallinn 2014, pp. 54-55; Annual Report 2013, Viking Line, pp. 41-51, Fjord Line Annual Report 2013, pp. 8-17.

Table 3 presents the revenue of selected companies operating the cruise fleet. Tallink-Silja Line's passengers service is the primary source of income. Sales on-board generate more than half the revenue of the group. In total, this item with ticket sales gives $85 \%$ the of yearly income. Freight has $11 \%$ share due to the high cargo turnover on Tallinn - Helsinki route.

Viking Line presents the consolidated data. The passenger segment generates $93 \%$ of the income and reflects the tourist quality of the company's business. The carrier offers low ticket prices and concentrates on sales at shops and restaurants. Taking into consideration the level of costs related to the purchase of goods for on-board services, one can assume that the structure of operator income from the passenger segment is the same as Tallink Group.

\section{Summary}

Cost and revenue are variables significantly influencing the financial results and performance of the ferry industry. The position of a ferry company is infle- 
xible due to the operation of the vessels on fixed routes according to sailing lists. The carrier incur costs irrespective of the utilization of a ferry's passenger and cargo capacity. The majority of costs in the ferry business should be regarded as fixed items. From the above analysis we may draw the following conclusions. For the companies operating cruise ferries the basic are on-board services, for those having ro-paxes obviously the cargo segment is essential. The management of cost and revenue are the key issues for the financial performance of a ferry operator.

\section{References}

Annual Report 2013, Viking Line, Mariehamn 2014.

AS Tallink Group Consolidated Annual Report 2013, Tallinn 2014.

Fjord Line Annual Report 2013, Oslo 2014.

Kizielewicz J., Urbanyi-Popiołek I., Rynek ustug morskiej żeglugi wycieczkowej, Wydawnictwo Naukowe PWN, Warszawa 2015.

Shippax Market, ShipPax Market Statistics, Plus 2 Ferryconsultation AB, Halmstad 2013.

Shippax Market, ShipPax Market Statistics, Plus 2 Ferryconsultation AB, Halmstad 2014.

Shippax Market, ShipPax Market Statistics, Plus 2 Ferryconsultation AB, Halmstad 2015.

Stopford M., Maritime Economics, Third edition, Routlege, London-New York 2009.

\section{EKONOMICZNE ASPEKTY DZIALALNOŚCI PRZEWOŹNIKÓW PROMOWYCH - WYBRANE ZAGADNIENIA}

\section{Streszczenie}

Żegluga promowa jest silnie rozwinięta na Morzu Bałtyckim. Eksploatacja promów jest jednym z typów żeglugi regularnej, a jej specyfiką jest jednoczesny transport pasażerów i ładunków. Koszty ponoszone przez operatorów są typowe dla operatorów działających w żegludze liniowej, natomiast przychody ze sprzedaży generowane są 
przez dwa odrębne segmenty. Celem artykułu jest analiza struktury kosztów i wpływów przedsiębiorstw promowych. Do analizy wybrano dwóch wiodących przewoźników eksploatujących promy typu cruise.

Słowa kluczowe: operator promowy, koszty, dochody 


\section{THE MARKET OF SEAPORT SERVICES}


